\title{
Pengaruh Word Of Mouth Dan Citra Perusahaan Terhadap Keputusan Penggunaan Jasa Ekspedisi JNE Express Di Kabupaten Buleleng
}

\author{
Ni Ketut Megah Purnama Sari ${ }^{* 1}$ Ni Made Dwi Ariani Mayasari² \\ 1,2Program Studi Manajemen, \\ Universitas Pendidikan Ganesha \\ Singaraja, Indonesia \\ e-mail: niketutmegahpurnamasari03@undiksha.ac.id ${ }^{* 1}$, \\ dwi.mayasari@undiksha.ac.id²
}

Riwayat Artikel
Tanggal
diajukan:
13 Februari
2021
Tanggal
diterima :
17 Mei 2021
Tanggal
dipublikasikan:
25 Juni 2021

Pengutipan:

Sari,N.K.M.P, Mayasari,

N.M.D.A.

(2021).

Pengaruh Word

of mouth Dan

Citra

Perusahaan

Terhadap

Keputusan

Penggunaan

Jasa Ekspedisi

Jne Express Di

Kabupaten

Buleleng. Jurnal

Pendidikan

Ekonomi

Undiksha,

13(1), 136-145

http://dx.doi.org/

10.23887/ijpe.v

$13 \mathrm{i} 1.32130$

\begin{abstract}
Abstrak
Penelitian ini bertujuan untuk menguji pengaruh word of mouth dan citra perusahaan baik secara simultan maupun parsial terhadap keputusan penggunaan jasa ekspedisi JNE Express di Kabupaten Buleleng. Dengan menggunakan desain penelitian kuantitatif kasual. Jumlah sampel dalam penelitian ini yaitu 100 responden, teknik sampel menggunakan teknik purposive sampling dengan pengambilan sampel.Teknik analisis data dalam penelitian ini adalah kuantitatif dengan menggunakan analisis regresi linier berganda. Hasil dari penelitian ini adalah (1) Word of mouth dan citra perusahaan berpengaruh signifikan secara simultan terhadap keputusan penggunaan jasa dengan sumbangan pengaruh sebesar $83,7 \%$. (2) Word of mouth berpengaruh signifikan secara parsial terhadap keputusan penggunaan jasa dengan sumbangan pengaruh sebesar $25,6 \%$. (3) Citra perusahaan berpengaruh signifikan secara parsial terhadap keputusan penggunaan jasa dengan sumbangan pengaruh sebesar $28,6 \%$.
\end{abstract}

Kata kunci: citra perusahaan; keputusan penggunaan jasa; word of mouth.

\begin{abstract}
This study was aimed to examine the effect of simultaneous and partially word of mouth and corporate image on use decisions of JNE Express Buleleng. The number of samples in this study were 100 respondents, the sample technique used purposive sampling. The data method used a questionnaire. The data analysis technique in this research is quantitative using multiple linear regression analysis. The result of the study showed that (1) word of mouth and corporate image has a positive and significant effect simultaneous on use decisions with a contribution influence of $83.7 \%$. (2) Word of mouth has a positive and significant effect partially on use decisions with a contribution influence of $25.6 \%$. (3) Corporate image has a positive and significant effect partially on with a use decisions contribution influence of $28.6 \%$.
\end{abstract}

Keywords : corporate image; word of mouth; use decisions.

\section{PENDAHULUAN}

Perusahaan jasa adalah perusahaan yang bergerak dibidang pelayanan. Manfaatnya dapat dirasakan secara langsung oleh konsumen. Perusahaan jasa memiliki peranan penting bagi seluruh masyarakat yang ada di dunia, termasuk perusahaan jasa logistik. Dimana banyaknya perusahaan jasa logistik dapat memudahkan masyarakat dalam pengiriman barang. Perusahaan jasa logistik merupakan perusahaan jasa yang menyediakan layanan jasa pengiriman barang dari tempat yang menggunakan 
jasa ke tempat tujuan. Berikut beberapa perusahaan yang bergerak dibidang jasa yaitu JNE, J\&T, TIKI dan lain sebagainya.

Persaingan perusahaan yang bergerak atau bergelut dibidang jasa ini semakin banyak. Perusahaan saling berlomba-lomba dalam meningkatkan kualitas pelayanan. Namun tidak semua perusahaan jasa memberikan pelayanan dengan baik, seperti contohnya keterlambatan barang sampai, keterangan posisi barang, salah pengiriman dan lainnya. Konsumen biasanya mencari informasi terlebih dahulu baik dari internet, media massa ataupun bertanya langsung kepada konsumen lainnya yang sudah pernah memakai jasa tersebut atau lainnya. Hal ini menyebabkan beberapa perusahaan jasa, memiliki citra perusahaan buruk atau baik dari berbagai informasi yang didapatkan, sehingga terbentuknya citra perusahaan jasa, melalui sekumpulan kesan konsumen, kepercayaan konsumen dan sikap konsumen.

Bagi perusahaan keputusan penggunaan jasa dari konsumen sangatlah penting karena hal tersebutlah yang akan menentukan pendapatan perusahaan tersebut. Keputusan penggunaan jasa mengarah pada, apakah konsumen akan menggunakan jasa tersebut atau tidak, selain itu keputusan penggunaan jasa mengarah pada perasaan senang atau kecewa dari konsumen atau seseorang yang muncul setelah membandingkan produk maupun jasa dari apa yang dipikirkan dengan apa yang diharapkan. Keputusan penggunaan jasa merupakan bagian dari perilaku konsumen. Jumlah konsumen dalam mengambil keputusan menjadi salah satu penentu tercapai atau tidaknya tujuan perusahaan. Menurut penelitian yang dilakukan oleh Rahardjo (2017) yang menyatakan bahwa keputusan penggunaan sama dengan keputusan pembelian konsumen. Menurut Schiffman \& Kanuk (2008) mendefinisikan keputusan sebagai pemilihan suatu tindakan dari dua pilihan alternatif atau lebih. Seorang konsumen yang hendak memilih, harus menentukan pilihannya. Menurut Kotler (1991) menjelaskan Keputusan pembelian merupakan tahap penilaian keputusan menyebabkan konsumen membentuk pilihan mereka diantara beberapa merek yang tergabung dalam perangkat pilihan.

Keputusan konsumen untuk memilih jasa ekspedisi yang diinginkan adalah suatu keputusan dimana konsumen melakukan pertimbangan-pertimbangan yang disesuaikan dengan kondisi yang ada. Jika kondisi yang terlihat tidak sesuai dengan apa yang diharapkannya, maka akan terjadi keraguan yang dapat berakibatkan pada keputusan untuk tidak memilih, dalam hal ini keputusan untuk tidak menggunakan jasa ekspedisi yang diharapkan. Pada kenyataanya pembuatan pilihan memiliki dimensi dan dampak baik maupun buruk, dimana memilih merupakan bagian dari proses penggambilan keputusan. Terkait proses pengambilan keputusan yang terjadi, tentunya konsumen pernah merasakan tahapantahapan dari mulai pengenalan kebutuhan, pencarian informasi, penilaian sampai kepada tahapan pengambilan keputusan. Konsumen biasanya mencari informasi terlebih dahulu baik dari internet, media massa ataupun bertanya langsung kepada konsumen lainnya yang sudah pernah memakai jasa tersebut atau lainnya. Namun konsumen lebih percaya terhadap informasi yang di peroleh dari konsumen lainnya daripada iklan dari jasa eksepedisi itu sendiri karena terkadang informasinya kurang relevan dengan realita yang terjadi. Menurut Ristiyanti \& Ihalauw (2005), word of mouth merupakan proses dimana informasi yang didapatkan oleh seseorang tentang suatu produk atau jasa dari interaksi sosial maupun dari pengalaman konsumsi yang diteruskan kepada orang lain. Selain itu menurut Jalivand (dalam Wijaya \& Paramita, 2014) menerangkan bahwa word of mouth berperan besar dalam pengambilan keputusan oleh konsumen dan dalam pembentukan pola perilaku konsumen. Word of mouth itu sendiri dirasa lebih efektif karena informasinya yang lebih reliabel.

Selanjutnya yang menjadi pertimbangan konsumen adalah mengenai citra perusahaan dari sebuah jasa ekspedisi. Hal ini menjadi sangat penting dan menjadi modal utama bagi perusahaan 
jasa ekspedisi. Dimana, citra perusahaanlah yang menentukan perusahaan ekspedisi itu baik atau buruk. Tetapi bukanlah perkara mudah bagi perusahaan jasa ekspedisi, bersaing. Kotler (2002), mendefisinikan citra sebagai jumlah dari keyakinan, gambaran dan kesan yang dimiliki seseorang pada suatu objek. Objek yang dimaksud bisa berupa orang, organisasi, kelompok orang atau yang lainnya yang dapat diketahui. Menurut Tang (2007), citra perusahaan adalah kesan yang muncul dalam pemikiran seseorang ketika mendengar nama dari sebuah perusahaan, hotel, restoran, atau intitusi bisnis lainnya. Menurut Nguyen et al. (2013) citra perusahaan merupakan hasil dari kumpulan proses dimana konsumen membandingkan berbagai atribut yang dimiliki oleh perusahan. Citra perusahan tidak hanya berdampak pada persepsi konsumen akan baik buruknya suatu perusahaan tapi bisa berdampak secara internal. Citra perusahaan yang baik dimaksudkan agar perusahaan dapat tetap hidup dan orang-orang didalamnya terus mengembangkan kreativitas bahkan memberikan manfaat yang lebih berarti bagi orang lain.
JNE Express merupakan perusahaan yang bergerak dalam jasa pengiriman yang didirikan pada tanggal 26 November 1990. JNE Express membuka cabang dikota-kota yang ada salah satunya ialah JNE Express di Kabupaten Buleleng. Berdasarkan observasi yang telah dilakukan bahwa di Kabupaten Buleleng, bisnis online banyak dilakukan oleh kalangan masyarakat maupun mahasiswa, konsumen melakukan bisnis melalui beberapa sosial media seperti instagram dan lain sebagainya, bukan hanya yang mempunyai bisnis online saja yang menggunakan jasa tersebut, bahkan kalangan masyarakat pun menggunakan jasa ini untuk keperluan pribadi. Berdasarkan pernyataan dari beberapa pelanggan JNE memperoleh hasil bahwa sering terjadi keterlambatan barang sampai, nomor resi pengiriman sering kali sulit dilacak, pengiriman tidak menjangkau pelosok, hanya terbatas pada kota-kota besar saja, dan lain sebagainya. Hal tersebut didukung oleh data penurunan angka peminat dan pengguna jasa ekspedisi JNE Express di Kabupaten Buleleng.

Tabel 1. Data Pengiriman Barang Perusahaan Jasa Ekspedisi di Kabupaten Buleleng (JNE dan J\&T diKabupaten Buleleng)

Pada Bulan Juni sampai Agustus tahun 2020

\begin{tabular}{cccccc}
\hline \multicolumn{2}{c}{ Juni } & \multicolumn{2}{c}{ Juli } & \multicolumn{2}{c}{ Agustus } \\
\hline Perusahaan & $\begin{array}{c}\text { Jumlah } \\
\text { Pengiriman } \\
\text { barang }\end{array}$ & Perusahaan & $\begin{array}{c}\text { Jumlah } \\
\text { Pengiriman } \\
\text { barang }\end{array}$ & Perusahaan & $\begin{array}{c}\text { Jumlah } \\
\text { Pengiriman } \\
\text { barang }\end{array}$ \\
\hline JNE & 7.000 & JNE & 6.000 & JNE & 1.320 \\
J\&T & 6.500 & J\&T & 7.200 & J\&T & 8.000 \\
\hline
\end{tabular}

Berdasarkan data di atas dapat dilihat bahwa perusahaan JNE Express mengalami penurunan selama 3 bulan terakhir, dimana pada bulan Juni sampai Agustus selalu mengalami penurunan, yang awalnya 7.000 pengiriman dalam sebulan, dan dibulan Agustus mengalami penurunan sejumlah 1.320 pengiriman. Dengan demikian peminat dari pengguna jasa JNE Express berkurang, sedangkan pengguna jasa JNT Express meningkat.
Keadaan yang dialami oleh JNE Express berbanding terbalik dengan teori yang dikemukakan oleh Hafilah (2015) bahwa word of mouth dan citra perusahaan berpengaruh positif, artinya apabila word of mouth dan citra perusahaan terhadap suatu perusahaan baik maka keputusan penggunaan jasa semakin meningkat. Namun terdapat kesenjangan penelitian yang dilakukan oleh Risti \& Usman (2017) menyatakan bahwa word of mouth 
berpengaruh negatif terhadap keputusan nasabah, dan menurut penelitian yang dikemukakan oleh Go et al. (2014) yang menyatakan bahwa citra perusahaan tidak berpengaruh terhadap keputusan penggunaan jasa.

Word of mouth memiliki peran penting dalam mempromosikan jasa. Dimana dampak dari WOM ini berpengaruh langsung kepada perusahaan. Dengan kata lain, konsumen tersebut akan berbicara kepada pelanggan lain yang berpotensial tentang pengalamannya dalam menerima jasa tersebut, sehingga word of mouth ini sangat besar pengaruhnya dan dampaknya terhadap pemasaran jasa dibandingkan dengan aktivitas komunikasi lainnya. Menurut Kotler dan Fox (dalam Sutisna, 2003) mengemukakan citra terhadap perusahaan berhubungan dengan sikap yang berupa keyakinan dan preferensi terhadap suatu perusahaan. Konsumen dengan citra yang positif terhadap suatu perusahaan, lebih memungkinkan untuk melakukan pembelian. Hal tersebut sejalan dengan penelitian Hafilah (2015) yang mengatakan bahwa word of mouth, dan citra merek mempunyai pengaruh signifikan terhadap keputusan penggunaan jasa keputusan mahasiswa memilih program Strata 1 (s1) di Universitas Negeri Maulana Malik Ibrahim Malang.

H1: Ada word of mouth dan citra perusahaan terhadap keputusan penggunaan jasa ekspedisi JNE Express di Kabupaten Buleleng.

Hubungan word of mouth terhadap keputusan pengguna jasa, yang dimana memiliki strategi promosi dalam kegiatan pemasaran yang menggunakan "orang ke orang" untuk meningkatkan kesadaran produk atau jasa dan menghasilkan tingkat penjualan tertentu. Komunikasi dari mulut ke mulut menyebar melalui jaringan bisnis, sosial dan masyarakat yang dianggap sangat berpengaruh (Hasan, 2010). Menurut Sumardy (2011) adalah tindakan penyedia informasi oleh seorang konsumen kepada konsumen lainnya. Komunikasi dari mulut ke mulut atau word of mouth communication merupakan tindakan konsumen memberikan informasi kepada konsumen lain dari seseorang kepada orang lain (antar pribadi) nonkomersial baik merek, produk maupun jasa. Word of mouth menjadi media yang paling kuat dalam mengkomunikasikan produk atau jasa kepada dua atau lebih konsumen. Word of mouth antar konsumen muncul secara alami dan jujur yang membuat pesan pemasaran yang dihasilkan jauh lebih baik efektif dibanding dengan media lain (Hasan, 2010). Word of mouth merupakan komunikasi yang menghasilkan percakapan yang baik. Seseorang akan bertanya kepada orang lain mengenai kualitas suatu barang atau jasa sebelum mereka memutuskan untuk membeli atau mengkonsumsinya. Oleh karena itu word of mouth dapat mempengaruhi keputusan penggunaan jasa seseorang dalam melakukan pembelian (Hill \& Sernovitz, 2009).

$\mathrm{H} 2$ : Ada pengaruh word of mouth terhadap keputusan penggunaan jasa ekspedisi JNE Express di Kabupaten Buleleng.

Citra perusahaan menjadi salah satu faktor yang yang digunakan konsumen sebagai acuan penilaian dalam memilih produk/jasa yang akan digunakan. Keputusan pelanggan dirasakan berdasarkan dari penilaian konsumen mengenai citra perusahaan itu, semakin baik citra perusahaan maka penilaian yang dilakukan atau diberikan oleh konsumen semakin baik juga. Hal tersebut sejalan dengan penelitian yang dilakukan Wahyuni (2018) citra perusahaan berpengaruh signifikan terhadap keputusan penggunaan jasa JNE cabang Kebumen.

H3: Ada pengaruh citra perusahaan keputusan penggunaan jasa ekspedisi JNE Express di Kabupaten Buleleng.

Adapun tujuan dari penelitian ini adalah untuk menguji pengaruh (1) word of mouth dan citra perusahaan terhadap keputusan penggunaan jasa ekspedisi JNE Express di Kabupaten Buleleng, (2) word of mouth terhadap keputusan penggunaan jasa ekspedisi JNE Express di Kabupaten Buleleng, dan (3) citra perusahaan terhadap keputusan penggunaan jasa ekspedisi JNE Express di Kabupaten Buleleng.

\section{METODE}


Penelitian ini dilaksanakan di Kabupaten Buleleng. Desain Penelitian yang digunakan dalam penelitian ini adalah kuantitatif kausal yaitu penelitian yang dilakukan untuk menguji hubungan sebab akibat yang dimana perubahan dari satu variabel menyebabkan perubahan pada variabel lain. Penelitian ini terdiri dari variabel bebas $(X)$ dan variabel terikat $(Y)$. Variabel bebas dalam penelitian ini adalah word of mouth (X1) dan citra perusahaan (X2) sedangkan variabel terikat dalam penelitian ini adalah keputusan penggunaan jasa (Y). Subjek dalam penelitian ini adalah konsumen JNE Express yang sudah pernah berbelanja di di Kabupaten Buleleng lebih dari 2 kali dalam 3 bulan terakhir. Sedangkan objek dalam penelitian ini adalah word of mouth, citra perusahaan dan keputusan penggunaan jasa.

Sampel merupakan bagian populasi yang digunakan untuk memperkirakan hasil dari suatu penelitian. Populasi dalam penelitian ini yaitu konsumen yang menggunakan jasa ekspedisi JNE Express di Kabupaten Buleleng. Bila jumlah populasi terlalu besar dan peneliti tidak mungkin mempelajari semua yang ada pada populasi dikarenakan keterbatasan dana, tenaga dan waktu maka peneliti dapat menggunakan sampel yang diambil dari populasi tersebut. Teknik pengumpulan sampel yang digunakan dalam penelitian ini yaitu teknik purposive sampling yaitu teknik penentuan sampel dengan kriteria atau karakteristik tertentu. Banyaknya jumlah sampel dalam penelitian tergantung dari jumlah parameter yang diestimasi. Pedomannya adalah 5-10 kali jumlah indikator yang diestimasi. Dalam penelitian ini menggunakan 10 indikator sehingga jumlah sampel atau responden penelitian minimal $10 \times 5=50$ dan jumlah sampel atau responden maksimal $10 \times 10$ $=100$. Pada penelitian ini menggunakan sampel maksimal yaitu sebanyak 100 responden untuk menghindari kurangnya response rate jika ada kuesioner yang tidak valid. Dalam penelitian ini, metode yang digunakan adalah survei. Alat atau instrumen yang digunakan adalah kuesioner. Data yang dikumpulkan dalam penelitian ini adalah data ordinal.

Penelitian ini bertujuan untuk menguji pengaruh word of mouth dan citra perusahaan terhadap keputusan penggunaan jasa ekspedisi JNE Express baik secara simultan maupun secara parsial, sehingga metode yang digunakan adalah analisis regresi linier berganda dengan bantuan program Statistical Product and Service Solution (SPSS). Analisis regresi linier berganda melibatkan lebih dari satu variabel bebas yang digunakan untuk mengetahui pengaruh terhadap variabel terikat.

\section{HASIL DAN PEMBAHASAN}

Penelitian ini menggunakan analisis regresi linier berganda karena melibatkan lebih dari satu variabel bebas untuk mengetahui pengaruhnya terhadap variabel terikat. Sebelum melakukan analisis regresi linier berganda, model regresi harus memenuhi syarat asumsi klasik yang terdiri dari uji normalitas, uji multtikolinieritas, dan uji heteroskedastisitas. Berdasarkan hasil penelitian, seluruh model regresi telah memenuhi syarat asumsi klasik sehingga model regresi layak digunakan untuk memprediksi pengaruh variabel bebas terhadap variabel terikat. Hasil analisis uji regresi linier berganda yang berupa rangkuman output SPSS dapat dilihat pada Tabel 2. berikut. 
Tabel 2. Hasil Pengujian Regresi Linier Beganda

\begin{tabular}{|c|c|c|c|c|c|}
\hline Parameter & Nilai & $P$ - Value & $\begin{array}{l}\text { Alpha } \\
(\alpha)\end{array}$ & Keputusan & Simpulan \\
\hline $\operatorname{Ryx}_{1} x_{2}$ & 0,892 & 0,000 & 0,05 & $\begin{array}{c}\text { Menolak } \\
\mathrm{H}_{0}\end{array}$ & $\begin{array}{l}\text { Ada pengaruh simultan dari } \\
\text { Word of mouth dan citra } \\
\text { perusahaan terhadap } \\
\text { keputusan penggunaan jasa }\end{array}$ \\
\hline $\mathrm{R}^{2}$ & 0,795 & - & - & - & $\begin{array}{l}\text { Menunjukkan variabel } \\
\text { keputusan penggunaan jasa } \\
\text { dapat dijelaskan dan } \\
\text { diterangkan dari kedua } \\
\text { variabel bebas yaitu word of } \\
\text { mouth dan citra perusahaan } \\
\text { menunjukkan pengaruh } \\
\text { sebesar } 79,5 \%\end{array}$ \\
\hline$\varepsilon$ & 0,205 & - & - & - & $\begin{array}{l}\text { Menunjukkan sebesar } 20,5 \% \\
\text { variabel keputusan } \\
\text { penggunaan jasa dijelaskan } \\
\text { dan diterangkan oleh variabel } \\
\text { lain. }\end{array}$ \\
\hline $\mathrm{PyX}_{1}$ & 0,466 & 0,000 & 0,05 & $\begin{array}{c}\text { Menolak } \\
\mathrm{H}_{0}\end{array}$ & $\begin{array}{l}\text { Ada pengaruh parsial dari } \\
\text { word of mouth terhadap } \\
\text { keputusan penggunaan jasa }\end{array}$ \\
\hline$P^{2} y X_{1}$ & 0,217 & - & - & - & $\begin{array}{l}\text { Menunjukkan besarnya } \\
\text { sumbangan pengaruh parsial } \\
\text { dari word of mouth terhadap } \\
\text { keputusan penggunaan jasa } \\
\text { yaitu sebesar } 21,7 \% \text {. }\end{array}$ \\
\hline $\mathrm{PyX}_{2}$ & 0.545 & 0,000 & 0,05 & $\begin{array}{c}\text { Menolak } \\
\mathrm{H}_{0}\end{array}$ & $\begin{array}{l}\text { Ada pengaruh parsial dari } \\
\text { citra perusahaan terhadap } \\
\text { keputusan penggunaan jasa }\end{array}$ \\
\hline$P^{2} y X_{2}$ & 0.297 & - & - & & $\begin{array}{l}\text { Menunjukkan besarnya } \\
\text { sumbangan pengaruh parsial } \\
\text { dari citra perusahaan } \\
\text { terhadap keputusan } \\
\text { penggunaan jasa yaitu } \\
\text { sebesar } 29,7 \% \text {. }\end{array}$ \\
\hline$\alpha$ & 1.878 & 0,000 & 0,05 & Signifikan & $\begin{array}{l}\text { Dapat memprediksi tingkat } \\
\text { keputusan penggunaan jasa. }\end{array}$ \\
\hline$\beta_{1}$ & 0,424 & 0,000 & 0,05 & Signifikan & $\begin{array}{l}\text { Dapat memprediksi tingkat } \\
\text { kepuasan pelanggan. }\end{array}$ \\
\hline$\beta_{2}$ & 0.499 & 0,000 & 0,05 & Signifikan & $\begin{array}{l}\text { Dapat memprediksi tingkat } \\
\text { keputusan penggunaan jasa. }\end{array}$ \\
\hline
\end{tabular}

Sumber : Hasil output spss analisis regresi linier berganda 
Berdasarkan rangkuman hasil analisis regresi linier berganda di atas maka diperoleh struktur hubungan antar variabel word of mouth, citra perushaan dan keputusan penggunaan jasa sebagai berikut.

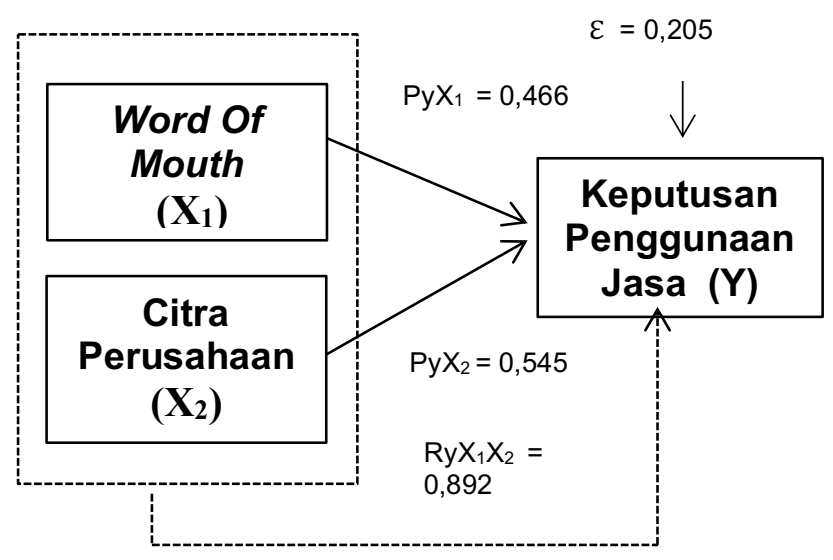

Keterangan :

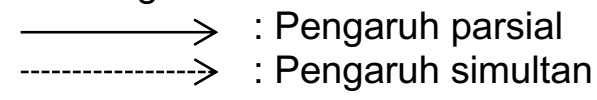

Gambar 1. Struktur Hubungan Pengaruh Word of Mouth dan Citra Perusahaan terhadap Keputusan Penggunaan Jasa ekspedisi JNE Express di Kabupaten Buleleng

Berdasarkan hasil analisis regresi linier berganda dan struktur hubungan di atas, maka diperoleh persamaan regresi sebagai berikut.

$\mathrm{Y}=1,878+0,424 \mathrm{X}_{1}+0,499 \mathrm{X}_{2}+0,205 \varepsilon$

Dari persamaan linier berganda tersebut menunjukkan bahwa:

1) Konstanta sebesar 1,878 , artinya bahwa apabila word of mouth $\left(\mathrm{X}_{1}\right)$ dan citra perusahaan $\left(X_{2}\right)$, nilainya sama dengan nol, maka keputusan penggunaan jasa (Y) sebesar 1,878.

2) Nilai koefisien word of mouth $\left(\beta_{1}\right)$ sebesar 0,424 berarti bahwa word of mouth $\left(X_{1}\right)$ berpengaruh positif terhadap keputusan penggunaan jasa $(Y)$. Hal ini mengandung arti bahwa setiap kenaikan word of mouth satu satuan maka variabel keputusan penggunaan jasa meningkat sebesar 0,424 sehingga menjadi 2,302
$(1,878+0,424)$, dengan asumsi bahwa variabel bebas yang lainnya tetap.

3) Nilai koefisien citra perusahaan $\left(\beta_{2}\right)$ sebesar 0,499 berarti bahwa citra perusahaan berpengaruh positif terhadap citra perusahaan (Y). Hal ini mengandung arti bahwa setiap kenaikan citra perusahaan satu satuan maka variabel keputusan penggunaan jasa meningkat sebesar 0,499 sehingga menjadi 2,377 (1,878+0,499), dengan asumsi bahwa variabel bebas yang lainnya tetap.

Berdasarkan rekapan hasil uji regresi linier berganda pada Tabel 2. menunjukan hasil $\mathrm{RyX}_{1} \mathrm{X}_{2}=0,892$ dengan $p$-value 0,000 < alpha 0,05, yang menyatakan bahwa menolak Ho yang berarti ada pengaruh word of mouth $\left(X_{1}\right)$ dan citra perusahaan $\left(X_{2}\right)$ terhadap keputusan penggunan jasa $(Y)$, dengan sumbangan pengaruh sebesar $83,7 \%$. Hasil tersebut menunjukan bahwa sebesar $79,5 \%$ keputusan penggunaan jasa $(Y)$ dipengaruhi oleh word of mouth $\left(\mathrm{X}_{1}\right)$ dan citra perusahaan $\left(\mathrm{X}_{2}\right)$. Sedangkan sisanya sebesar $20,5 \%$ dipengaruhi oleh variabel lainnya. Maka dapat disimpukan bahwa variabel word of mouth dan citra perusahaan secara bersama-sama berperan dalam meningkatkan keputusan penggunaan jasa.

Berdasarkan rekapan hasil uji regresi linier berganda pada Tabel 2. menunjukkan hasil $\mathrm{PyX}_{1}=0,466$ dengan $p$-value $0,000<$ alpha 0,05 hal ini menyatakan bahwa menolak Ho yang berarti ada pengaruh word of mouth $\left(\mathrm{X}_{1}\right)$ terhadap keputusan penggunaan jasa $(\mathrm{Y})$, dengan sumbangan pengaruh sebesar $21,7 \%$. Maka dapat disimpukan bahwa variabel word of mouth berperan dalam meningkatkan keputusan penggunaan jasa.

Berdasarkan rekapan hasil uji regresi linier berganda pada Tabel 2. menunjukan hasil $\mathrm{PyX}_{2}=0,545$ dengan $p$-value 0,000< alpha 0,05 hal ini menyatakan bahwa menolak Ho yang berarti ada pengaruh citra perusahaan $\left(\mathrm{X}_{2}\right)$ terhadap keputusan penggunaan jasa $(Y)$, dengan sumbangan pengaruh sebesar 29,7\%. Maka dapat disimpukan bahwa variabel citra perusahaan berperan dalam meningkatkan keputusan penggunaan jasa. 
Pengaruh Word of Mouth Dan Citra Perusahaan Terhadap Keputusan Penggunaan Jasa

Word of mouth dan citra perusahaan berperngaruh positif dan signifikan terhadap keputusan penggunaan jasa ekspedisi JNE Express. Word of mouth memiliki peran penting dalam mempromosikan jasa. Dimana dampak dari word of mouth ini berpengaruh langsung kepada perusahaan. Dengan kata lain, konsumen tersebut akan berbicara kepada pelanggan lain yang berpotensial tentang pengalamannya dalam menerima jasa tersebut, sehingga word of mouth ini sangat besar pengaruhnya dan dampaknya terhadap pemasaran jasa dibandingkan dengan aktivitas komunikasi lainnya. Menurut Kotler dan Fox (dalam Sutisna, 2003) mengemukakan citra terhadap perusahaan berhubungan dengan sikap yang berupa keyakinan dan preferensi terhadap suatu perusahaan. Konsumen dengan citra yang positif terhadap suatu perusahaan, lebih memungkinkan untuk melakukan pembelian. Hal tersebut sejalan dengan penelitian Hafilah (2015) yang mengatakan bahwa word of mouth, dan citra merek mempunyai pengaruh signifikan terhadap keputusan penggunaan jasa keputusan mahasiswa memilih program Strata 1 (S1) di Universitas Negeri Maulana Malik Ibrahim Malang.

Dalam meningkatkan word of mouth yang baik dari pelanggan, hal yang dapat dilakukan oleh JNE Express yaitu dengan memenuhi kebutuhan dan keinginan pelanggan sesuai dengan yang diharapkan sehingga pelanggan akan merasa puas, sehingga menyebarkan word of mouth yang positif. Selain itu perusahaan juga perlu meningkatkan citra perusahaan, dengan cara memberikan kesan yang baik kepada pelanggan. Ketika word of mouth dan citra perusahaan telah baik dikalangan masyarakat maka akan dengan mudah pelanggan memutuskan untuk menggunakan jasa tersebut

\footnotetext{
Pengaruh Word Of Mouth Terhadap Keputusan Penggunaan Jasa

Word of mouth berperngaruh positif dan signifikan keputusan penggunaan jasa ekspedisi JNE Express. Komunikasi dari mulut ke mulut menyebar melalui jaringan
}

bisnis, sosial dan masyarakat yang dianggap sangat berpengaruh (Hasan, 2010) . Menurut Sumardy (2011) adalah tindakan penyedia informasi oleh seorang konsumen kepada konsumen lainnya. Komunikasi dari mulut ke mulut atau word of mouth communication merupakan tindakan konsumen memberikan informasi kepada konsumen lain dari seseorang kepada orang lain (antar pribadi) nonkomersial baik merek, produk maupun jasa. Word of mouth menjadi media yang paling kuat dalam mengkomunikasikan produk atau jasa kepada dua atau lebih konsumen. Word of mouth antar konsumen muncul secara alami dan jujur yang membuat pesan pemasaran yang dihasilkan jauh lebih baik efektif dibanding dengan media lain (Hasan, 2010). Word of mouth merupakan komunikasi yang menghasilkan percakapan yang baik. Seseorang akan bertanya kepada orang lain mengenai kualitas suatu barang atau jasa sebelum konsumen memutuskan untuk membeli atau mengkonsumsinya. Oleh karena itu word of mouth dapat mempengaruhi keputusan penggunaan jasa seseorang dalam melakukan pembelian (Hill \& Sernovitz, 2009).

Sebagai perusahaan yang bergerak di bidang perusahaan jasa, word of mouth dari pelanggan merupakan hal yang sangat penting bagi perusahaan, karena jika word of mouth baik keputusan penggunaan jasa semakin meningkat. Maka dari itu sangat penting bagi JNE Express untuk memenuhi kebutuhan dan keinginan pelanggan sesuai dengan yang diharapkan sehingga pelanggan akan merasa puas. JNE Express dapat meningkatkan word of mouth dengan cara menyediakan website dengan fasilitas ruang obrol, kolom komentar atau review sehingga pelanggan dapat menyampaikan kritik atau saran kepada pihak JNE Express yang dapat nantinya digunakan untuk evaluasi kinerja perusahaan. Jika dilihat dari karakteristik responden yaitu sebagian besar perempuan dan berprofesi sebagai pelajar atau mahasiswa maka hal yang dapat dilakukan untuk meningkatkan word of mouth positif adalah dengan cara mengarahkan pelanggan untuk memberikan review melalui media sosial 
seperti Instagram. Karena pelajar atau mahasiswa adalah kaum milenial sehingga akan sangat mudah jika review disampaikan melalui media sosial. Sehingga keluh kesah pelanggan tidak hanya dipendam kemudian dapat menjadi word of mouth negatif, namun dapat disampaikan dengan baik berupa saran dimedia yang telah disediakan oleh perusahaan.

\section{Pengaruh Citra Perusahaan Terhadap Keputusan Penggunaan Jasa \\ Citra perusahaan berperngaruh} positif dan signifikan terhadap keputusan penggunaan jasa ekspedisi JNE Express di Kabupaten Buleleng. Citra perusahaan menjadi salah satu faktor yang yang digunakan konsumen sebagai acuan penilaian dalam memilih produk/jasa yang akan digunakan. Keputusan pelanggan dirasakan berdasarkan dari penilaian konsumen mengenai citra perusahaan itu, semakin baik citra perusahaan maka penilaian yang dilakukan atau diberikan oleh konsumen semakin baik juga. Hal tersebut sejalan dengan penelitian yang dilakukan Wahyuni (2018) citra perusahaan berpengaruh signifikan terhadap keputusan penggunaan jasa JNE cabang Kebumen. Dengan demikian dapat disimpulkan bahwa, citra perusahaan merupakan pandangan atau presepsi konsumen terhadap perusahaan yang berhubungan dengan nama bisnis, citra baik atau buruk perusahaan, kualitas yang sengaja diciptakan sebagai cermin dari identitas sebuah perusahaan dan lain sebagainya

Dalam hal meningkatkan citra perusahaan perusahaan harus mampu memberikan jaminan kepada pelanggan bahwa barang yang dikirimkan sampai dengan aman dan sesuai dengan target yang diinginkan pelanggan seperti jargon yang dimiliki JNE yaitu YES (Yakin Esok Sampai). Selain itu JNE juga perlu mengoptimalkan sistem tracking atau pelacakan yang dimiliki agar konsumen dapat dengan mudah melacak keberadaan barang yang dikirimnya. Mengingat mayoritas konsumen JNE yaitu pelajar atau mahasiswa yang peka akan teknologi maka sangat dipandang perlu bagi JNE untuk meningkatkan teknologi yang dimiliki sehingga citra JNE dikalangan konsumennya juga akan baik. Ketika JNE sudah mampu membangun citra yang baik maka akan dengan mudah JNE mempertahankan konsumennya. Karena konsumen akan cenderung memilih JNE sebagai penyedia jasa pengiriman karena citra baik yang dimilikinya. Maka dapat dikatakan bahwa citra dapat mempengaruhi keputusan penggunaan dari konsumen.

\section{SIMPULAN DAN SARAN}

Penelitian ini dilatar belakangi oleh menurunnya keputusan penggunaan jasa ekspedisi JNE Express pada bulan juni sampai agustus tahun 2020, selain itu banyaknya keluhan dari konsumen atas jasa ekspedisi JNE Express berupa lamanya waktu barang sampai, keterbatasan pengiriman ke daerah pelosok dimana penerima barang harus datang ke kantor cabang JNE Express untuk mengambil barang tersebut, sistem pelacakan atau tracking dengan menggunakan nomor resi yang rumit dan sebagainya.

Berdasarkan hasil dan pembahasan yang dilakukan, maka dapat ditarik kesimpulan dalam penelitian ini sebagai berikut, (1) word of mouth dan citra perusahaan berpengaruh signifikan secara simultan terhadap keputusan penggunaan jasa ekspedisi JNE Express di Kabupaten Buleleng, (2) word of mouth berpengaruh signifikan secara parsial terhadap keputusan penggunaan jasa ekspedisi JNE Express di Kabupaten Buleleng, (3) citra perusahaan berpengaruh signifikan secara parsial terhadap terhadap keputusan penggunaan jasa ekspedisi JNE Express di Kabupaten Buleleng.

Berdasarkan hasil penelitian dan pembahasan, serta simpulan yang telah dipaparkan, maka saran yang dapat diberikan sebagai berikut. (1) Bagi peneliti diharapkan agar selanjutnya dapat mengembangkan penelitian ini dengan menambahkan variabel-variabel lain yang memengaruhi keputusan penggunaan jasa dan dapat memperbanyak teori tentang variabel yang digunakan serta dapat menggunakan teknik analisis data yang lain 
agar dapat menjadi acuan dari penelitianpenelitian selanjutnya dan dapat menambah wawasan keilmuan khususnya dalam Manajemen Pemasaran. (2) Bagi pihak JNE Express, diharapkan dapat mengembangkan berbagai strategi dalam meningkatkan word of mouth dan citra perusahaan agar terwujudnya keputusan penggunaan jasa. Sehingga pada tahun berikutnya perusahaan jasa Ekspedisi JNE Express di Kabupaten Buleleng dapat kembali mengalami peningkatan dan semakin dipercaya perusahaan jasa Ekspedisi JNE Express di Kabupaten Buleleng dikalangan masyarakat.

\section{DAFTAR PUSTAKA}

Go, M. E., Lapian, J., \& Moniharapon, S. (2014). Citra Perusahaan Dan Kualitas Pelayanan Pengaruhnya Terhadap Keputusan Menggunakan Jasa Pada Sekolah Mengemudi Melati di Manado. Jurnal EMBA: Jurnal Riset Ekonomi, Manajemen, Bisnis Dan Akuntansi, 2(3).

Hafilah, E. (2015). Pengaruh Word of Mouth (WOM) dan Citra Merek terhadap Keputusan Mahasiswa Memilih Program Strata 1 (S-1) di Universitas Islam Negeri Maulana Malik Ibrahim Malang. Universitas Islam Negeri Maulana Malik Ibrahim.

Hasan, A. (2010). Marketing dari Mulut ke Mulut. Yogyakarta.

Hill, M. G., \& Sernovitz. (2009). Word of Mouth Marketing. Jakarta.

Kotler, P. (1991). Manajemen Pemasaran: Analisa Perencanaan, Implementasi, dan Pengendalian. Jakarta: Erlangga.

Kotler, P. (2002). Manajemen Pemasaran, Edisi Millenium. Prenhallindo.

Nguyen, N., Leclerc, A., \& LeBlanc, G. (2013). The Mediating Role of Customer Trust on Customer Loyalty. Journal of Service Science and Management, 6(1), 96-109.

Rahardjo, M. (2017). Studi Kasus dalam Penelitian Kualitatif Konsep dan Prosedurnya. Jurnal IImiah. Malang: Universitas Islam Negeri Maulana Malik Ibrahim Malang.

Risti, A. P. E., \& Usman, M. N. (2017). Pengaruh Promosi Penjualan, Citra Merek, Dan Nilai Yang Dirasakan
Dengan Variabel Intervening WOM Terhadap Keputusan Penggunaan Kartu Kredit. Journal of Business and Banking, 6(1), 99-112.

Ristiyanti, P., \& Ihalauw, J. J. O. I. (2005). Perilaku Konsumen. Yogyakarta: ANDI.

Schiffman, L. G., \& Kanuk, L. L. (2008). Perilaku Konsumen. Jakarta: Indeks.

Sumardy. (2011). The Power of Word of Mouth Marketing.

Sutisna. (2003). Perilaku Konsumen dan Komunikasi Pemasaran. Bandung: PT. Remaja Rosdakarya.

TANG, W. (2007). Impact Of Corporate Image And Corporate Reputation On Customer Loyalty: A Review. Management Science and Engineering, 1(2), 57-62.

Wahyuni, D. (2018). Analisis Pengaruh Kualitas Pelayanan, Citra Perusahaan Dan Word of Mouth Terhadap Keputusan Penggunaan Jasa (Studi Pada Pengguna.

Wijaya, T., \& Paramita, L. (2014). Pengaruh Electronic Word of Mouth (Ewom) Terhadap Keputusan Pembelian Kamera Dslr. 